\title{
Ketahanan Bisnis Perkeretaapian di Masa Pandemi COVID - 19
}

\author{
Hengki Purwoto ${ }^{1,2}$, hengkipurwoto@ugm.ac.id \\ Wakhid Slamet Ciptono ${ }^{1,2}$, wakhidsciptono@ugm.ac.id \\ Agus Taufik Mulyono1,3, agus.taufik.mulyono@ugm.ac.id \\ Arif Wismadi ${ }^{1,4}$, arif.wismadi@ugm.ac.id \\ Imam Muthohar ${ }^{1,3}$,imam.muthohar@ugm.ac.id \\ Dwi Ardianta Kurniawan*1, dwiardianta@ugm.ac.id \\ ${ }^{1}$ Pusat Studi Transportasi dan Logistik (Pustral), Universitas Gadjah Mada \\ ${ }^{2}$ Fakultas Ekonomika dan Bisnis, Universitas Gadjah Mada \\ ${ }^{3}$ Departemen Teknik Sipil dan Lingkungan, Fakultas Teknik, Universitas Gadjah Mada \\ ${ }^{4}$ Departemen Teknik Arsitektur dan Perencanaan, Fakultas Teknik, Universitas Gadjah Mada
}

\begin{abstract}
ABSTRAK
Pembatasan operasional kereta api di masa pandemi COVID-19 berdampak pada penurunan volume dan pendapatan angkutan penumpang dan barang KA di Indonesia. Kebijakan yang dapat diterapkan untuk mengatasi dampak pandemi mencakup Optimasi Operasi yang berbasis efisiensi operasi, serta Adaptasi Pandemi yang berbasis minimalisasi kondisi 3C (Closed Space, Crowded Place, Closed Contact Setting). Dampak penerapan kebijakan tersebut perlu disimulasikan pengaruhnya terhadap biaya operasi (BO) dan pendapatan operasi (PO). Hasil perbandingan nilai PO dan BO (POBO), menjadi indikator seberapa kuat bisnis perkeretaapian mampu bertahan di masa pandemi. Hasil perhitungan menunjukkan nilai POBO kedua kebijakan adalah 1,08 (kebijakan optimasi) dan 1,09 (kebijakan adaptasi pandemi). Profil ini menunjukkan ketahanan bisnis perkeretaapian berada pada ambang batas nilai Break Event Point (BEP), jauh di bawah nilai POBO pada tahun-tahun sebelum. Hal ini memperlihatkan bahwa dampak pandemi sangat signifikan terhadap cash flow perusahaan. Titik kritis shutdown point terjadi pada volume barang dan penumpang hingga sebesar $40 \%$ dibandingkan tahun 2019. Volume tersebut lebih rendah dibandingkan kondisi saat ini yaitu volume penumpang sebesar $50,5 \%$ - 55,5\%; serta volume barang sebesar 81,5\% dibandingkan volume tahun 2019. Besaran ini menunjukkan bahwa bisnis perkeretaapian masih memiliki daya tahan sebelum mengalami titik kritis shutdown point.

Kata Kunci: COVID - 19, 3C, POBO, break event point, shutdown point.
\end{abstract}

\section{ABSTRACT}

The COVID-19 pandemic has resulted in decreasing on volume and revenue railway passenger and freight in Indonesia. Policies that can be implemented to overcome the impact of a pandemic include Operational Optimization based on operating efficiency, and Pandemic Adaptation based on minimizing 3C conditions. (Closed Space, Crowded Place, Closed Contact Setting). The impact of implementing the policy needs to be simulated its effect on operating costs (BO) and operating income (PO). The results of the comparison of $P O$ and $B O$ values, hereinafter referred to as $P O B O$, are an indicator of how strong the railway business is able to survive during a pandemic. The calculation results show that the POBO values of the two policies are 1.08 (optimization policy) and 1.09 (pandemic adaptation policy). This profile shows the resilience of the railroad business at the threshold value of the Break Event Point (BEP), far below the POBO value in previous years. This shows that the impact of the pandemic is very significant on the company's cash flow. The critical point for the shutdown point occurred in the volume of goods and passengers by up to $40 \%$ compared to the volume in 2019. This volume was lower than the basic calculation, namely passenger volume of 50.5\% - 55.5\%; and the volume of goods by $81.5 \%$ compared to the volume in 2019. This figure shows that the railroad business still has resilience before experiencing a critical shutdown point.

Keywords: COVID - 19, 3C, POBO, break event point, shutdown point.

\section{PENDAHULUAN}

Pandemi COVID - 19 menyebabkan terjadinya pembatasan operasional kereta api di Indonesia yang berdampak pada penurunan kinerja operasi dan finansial. Dampak dominan pembatasan operasi tersebut terjadi pada angkutan orang, sehingga terdapat penurunan dari 236,4 juta penumpang pada Semester I 2019 menjadi 111,1 juta pada Semester I - 
2020, atau turun 53\%. Pada sisi finansial, terjadi penurunan pendapatan angkutan penumpang dari Rp4,328 T menjadi Rp2,034 T (turun 53\%). Pada angkutan barang, secara volume terjadi penurunan dari 23,05 juta ton pada Semester I - 2019 menjadi 21,9 juta ton pada Sementer I - 2020, atau turun sekitar 5\%, setara dengan penurunan pendapatan dari Rp3,32 T menjadi Rp3,16 T (PT. Kereta Api Indonesia - PT. KAI, 2020).

Profil tersebut menunjukkan pertamakali pendapatan angkutan barang lebih besar dibandingkan angkutan penumpang (ekonomi.bisnis.com, 2020). Angkutan barang menjadi peluang PT. KAI untuk memaksimalkan sarana yang dimiliki untuk mengangkut alat kesehatan dan kebutuhan bahan pokok dari Jawa Timur ke Jakarta atau sebaliknya. Dengan berbagai strategi yang dilakukan, PT KAI tidak melakukan pemutusan hubungan kerja (PHK) terhadap pegawai yang berjumlah 47.000 orang (beritasatu.com, 2020).

Penurunan signifikan angkutan penumpang kereta api terjadi di seluruh dunia. Di Perancis dan Italia, volume angkutan penumpang turun hingga $90 \%$, sementara angkutan barang turun antara 20\% hingga 35\% (railwaypro.com, 2020). Di London, penurunan penumpang terjadi sebesar $70 \%$, sementara di Spanyol, penurunan terjadi hingga 95\% (www.rtands, 2020). Di Asean, aktifitas angkutan barang antar kota turun 53\%, sementara angkutan barang dalam kota turun 16\% (ITF, 2020).

Secara global, the International Union of Railways (UIC, 2020) memperkirakan akibat ketatnya pembatasan wilayah yang diberlakukan oleh pemerintah, pembatasan perjalanan, resesi global dan model pemulihan yang lambat, pendapatan penumpang dan barang turun hingga total $\$ 125$ miliar untuk tahun 2020 dan 2021. Pada kondisi pemulihan cepat, yaitu pemulihan dicapai tahun 2021, UIC memperkirakan pendapatan penumpang dan kargo turun hingga $\$ 78$ miliar.

Beberapa kajian telah dilakukan untuk mengukur besaran dampak COVID 19 terhadap transportasi. Kajian yang dilakukan oleh Aloi et al (2020) menganalisis dampak perubahan pola perjalanan terhadap kualitas udara dan kecelakaan di Santander, Spanyol. Terjadi penurunan mobilitas sebesar $76 \%$ pada mobil pribadi dan $93 \%$ pada angkutan umum. Di sisi lain, emisi udara juga turun $60 \%$, kecelakaan turun $67 \%$. Dengan demikian,turunnya mobilitas berdampak pada peningkan kualitas udara dan turunnya kecelakaan. Namun demikian, terdapat risiko ketidakberlanjutan angkutan umum di perkotaan karena minimnya demand.

Zhang and Hayashi (2020) mengkaji dampak COVID 19 pada sektor transport dan kebutuhan kebijakan di masa mendatang. Terjadi peralihan penggunaan moda dari angkutan umum ke mobil pribadi $(64.8 \%)$, berjalan $(42.3 \%)$, sepeda $(35.6 \%)$, dan sepeda motor $(19.7 \%)$. Perubahan pola mobilitas tersebut disebabkan oleh perubahan pola hidup (online working, ketergantungan mobil pribadi, online shopping). Dampak yang muncul adalah potensi ketergantungan pada kendaraan pribadi, dipengaruhi oleh kebijakan angkutan umum, industri, gaya hidup, dan perilaku konsumen.

Falchetta dan Noussan (2020) mengkaji dampak COVID 19 pada permintaan transport, pemilihan moda dan konsumsi energi di Eropa. Permintaan transport akan tetap rendah karena gaya hidup baru (teleworking, telemarketing, dll), pemulihan angkutan barang tergantung pemulihan ekonomi, serta terdapat ketidakpastian konsumsi energi transport. Dampak yang muncul adalah kebutuhan dukungan untuk pemerintah daerah dan perusahaan transport karena turunnya pendapatan.

Hasil kajian dari World Bank (2017) menunjukkan bahwa biaya satuan operasi penyelenggaraan kereta api sangat dipengaruhi oleh volume yang diangkut. Biaya satuan akan sangat sensitif pada volume lalulintas yang rendah (di bawah 5 juta per tahun sebagaimana terlihat pada Gambar 1 berikut: 


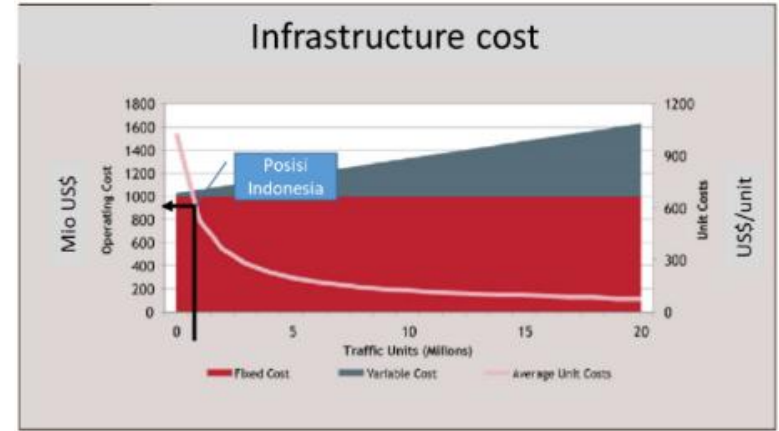

Sumber: the World Bank, 2017

Gambar 1. Infrastructure Cost dan Operating Cost Perkeretaapian

Berdasarkan data Grafik Perjalanan Kereta Api (Gapeka) tahun 2019, jumlah pergerakan kereta di Indonesia adalah 758.835 gerakan per tahun. Hal ini menunjukkan, bahwa penurunan volume operasi akan signifikan menaikkan biaya satuan.

Kajian Preston and Bickel (2020) menunjukkan bahwa dalam kasus operasi di Inggris, pengurangan densitas operasi tidak mengurangi biaya operasi, namun signifikan mengurangi penerimaan operasi. Pada masa pandemi, dengan penurunan permintaan hingga $70 \%$, pemerintah menunda perjanjian kontrak dengan skema franchise dan mengubah dengan kontrak manajemen dengan fee hingga $2 \%$ dibandingkan biaya sebelum COVID - 19.

Sementara kajian Chen et al. (2020) menunjukkan bahwa protokol kesehatan dengan menerapkan digitalisasi meningkatkan biaya operasi dan investasi sistem. Praktik di Wuhan dengan pengendalian lalulintas selama 76 hari efektif menurunkan penyebaran virus. Beberapa perusahaan telah mengembangkan teknologi kendaraan yang mendukung keselamatan dan kesehatan bagi pengendara dan penumpang.

Kajian literatur menunjukkan bahwa penelitian yang telah dilakukan belum membahas mengenai seberapa besar penurunan produktvitas (volume, pendapatan) yang dapat ditoleransi oleh sektor perkeretaapian. Kajian tersebut diperlukan untuk mengetahui seberapa kuat ketahanan bisnis sektor perkeretaapian di masa pandemi. Penerapan kebijakan di era pandemi seperti Optimasi Operasi yang

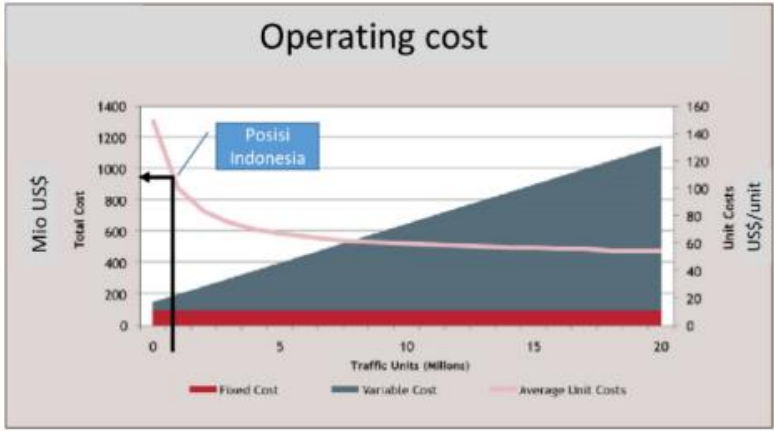

berbasis efisiensi operasi, serta Adaptasi Pandemi yang berbasis minimalisasi kondisi 3C (Closed Space, Crowded Place, Closed Contact Setting), perlu disimulasikan pengaruhnya terhadap biaya operasi (BO) dan pendapatan operasi (PO). Hasil perbandingan PO dengan BO tersebut akan menjadi indikator seberapa kuat bisnis perkeretaapian mampu bertahan di masa pandemi.

\section{METODOLOGI}

\subsection{Metode Pengumpulan Data}

Metode yang dipergunakan dalam kajian termasuk dalam metode kuantitatif, dengan menggunakan data dan indikator yang bersifat numerik. Data yang digunakan adalah data sekunder yang bersumber dari operator kereta api di Indonesia, yaitu PT. Kereta Api Indonesia (KAI). Data yang digunakan adalah Laporan Keuangan PT. KAI pada rentang 2014 - 2019. Selain itu, dipergunakan juga data dari Direktorat Jenderal Perkeretaapian (DJKA) berupa volume penumpang dan barang melalui KA pada tahun 2019 (data historis) dan 2020 (data historis dan proyeksi).

\subsection{Pengolahan Data}

Data diolah secara matematis untuk mendapatkan beberapa indikator:

a. Pendapatan operasi terdampak, dengan membentuk fungsi pendapatan terhadap volume penumpang dan barang.

b. Biaya operasi terdampak, dengan membentuk fungsi biaya operasi terhadap volume penumpang dan barang.

c. Ketahanan bisnis, dengan metode perhitungan Pendapatan Operasi (PO) / 
Biaya Operasi (BO) atau disingkat POBO.
Untuk memprediksi besaran pendapatan dan biaya operasi terdampak intervensi kebijakan, dipergunakan asumsi-asumsi sebagaimana disajikan dalam Tabel 1.

Tabel 1. Intervensi Kebijakan dan Implikasinya

\begin{tabular}{|c|c|c|}
\hline Intervensi & Optimasi Operasi & Adaptasi Pandemi \\
\hline $\begin{array}{l}\text { Operasionalisasi } \\
\text { kebijakan }\end{array}$ & - $\quad$ Efisiensi Opex dan Capex & $\begin{array}{l}\text { - Pencegahan crowded place, closed } \\
\text { space, close contact setting (3C) }\end{array}$ \\
\hline $\begin{array}{l}\text { Implikasi } \\
\text { operasional }\end{array}$ & $\begin{array}{l}\text { - Pengurangan kapasitas sarana, penurunan } \\
\text { penumpang }\end{array}$ & $\begin{array}{l}\text { - Pengurangan kapasitas sarana, } \\
\text { penurunan penumpang } \\
\text { Redesain sarana untuk mencegah } \\
\text { closed space }\end{array}$ \\
\hline Implikasi finansial & $\begin{array}{l}\text { - Penurunan biaya, penurunan pendapatan } \\
\text { akibat penurunan operasi } \\
\text { Kenaikan biaya operasi akibat penerapan } \\
\text { protokol COVID }\end{array}$ & $\begin{array}{l}\text { - Penurunan biaya, penurunan } \\
\text { pendapatan akibat penurunan } \\
\text { penumpang dan barang } \\
\text { Kenaikan biaya akibat penerapan } \\
\text { protokol COVID, pencegahan closed } \\
\text { space }\end{array}$ \\
\hline $\begin{array}{l}\text { Nilai } \\
\text { finansial }\end{array}$ & $\begin{array}{l}\text { - Penurunan capex dan opex } \operatorname{Rp} 3,8 \mathrm{~T} \text {; } \\
\text { relaksasi kredit Rp934 M; pengurangan } \\
\text { pajak Rp316,3 } \mathrm{M}^{*} \\
\text { Kenaikan biaya operasi } 5 \% \text { untuk } \\
\text { penerapan protokol COVID ** }\end{array}$ & $\begin{array}{l}\text { - Kenaikan } 10 \% \text { penumpang karena } \\
\text { penerapan 3C secara konsisten*** } \\
\text { - Kenaikan biaya operasi } 10 \% \text { untuk } \\
\text { penerapan protokol COVID dan } \\
\text { pencegahan 3C *** }\end{array}$ \\
\hline
\end{tabular}

Sumber: * Paparan PT. KAI ** wawancara narasumber *** interpretasi hasil survei stated preference

Sumber: PT. KAI, 2020

\subsection{Analisis Data}

Analisis data dilakukan untuk mengetahui ketahanan bisnis penyelenggaraan perkeretaapian, dengan indikator nilai $\mathrm{PO} / \mathrm{BO}$ yang dihasilkan. Titik kritis yang perlu diperhatikan untuk menganalisis tingkat ketahanan bisnis adalah titik break event point (BEP) dan shut down point (SDP). Pada kondisi BEP, pendapatan perusahaan memiliki nilai yang sama dengan biaya (tetap dan variabel). Pada kondisi ini, bisnis masih dapat berjalan selama pendapatan masih dapat menutup biaya variabel. Keputusan untuk menutup bisnis harus dilakukan ketika $\mathrm{PO} / \mathrm{BO}$ mencapai titik SDP sebagaimana secara grafis disajikan dalam Gambar 2 berikut:

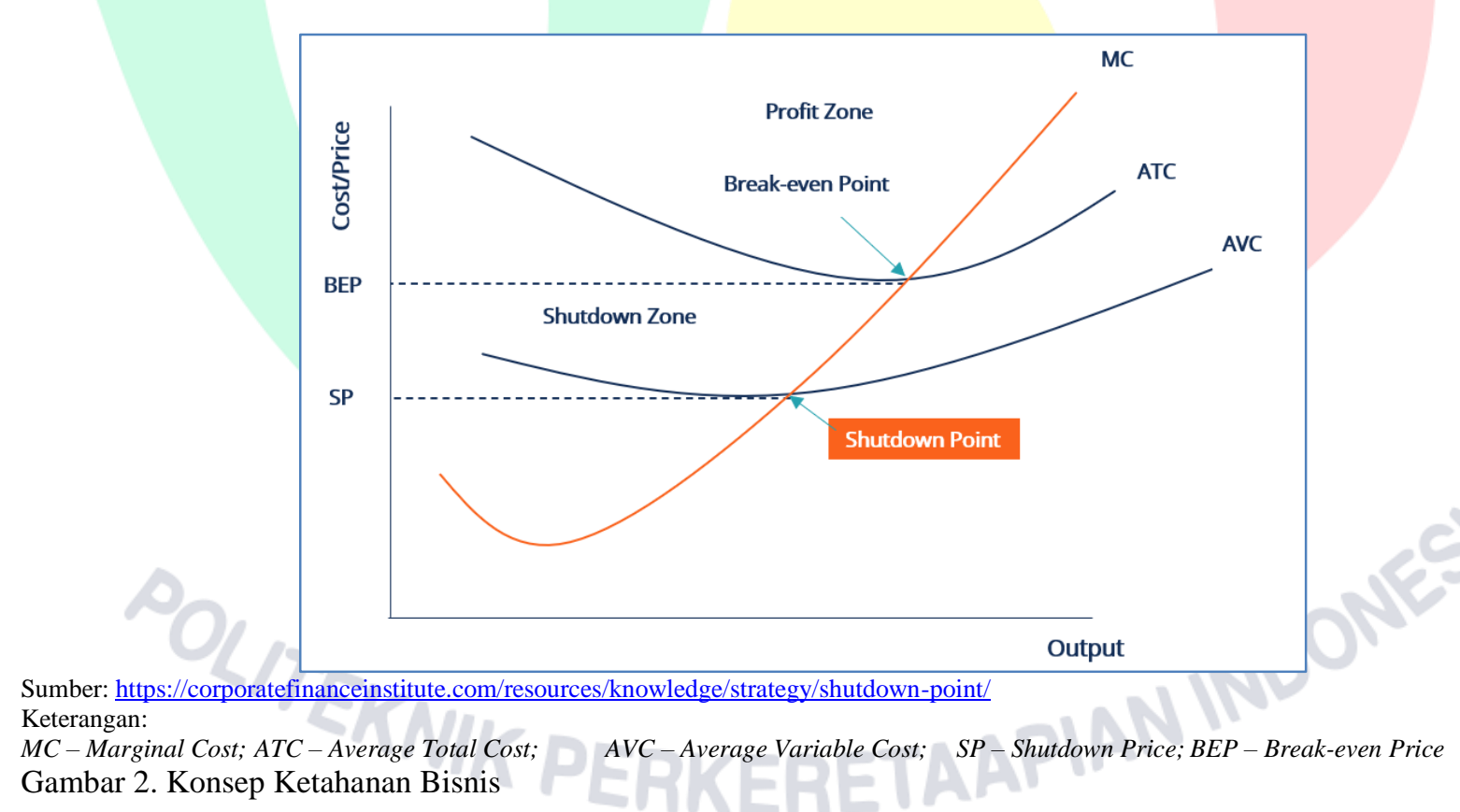


Dalam jangka panjang, perusahaan harus keluar dari bisnis apabila nilai POBO di bawah 1 dan pendapatan tidak meningkat. Dalam jangka pendek, keputusan bervariasi tergantung pada tingkat kerugian dan apakah perusahaan dapat menutupi biaya variabelnya.

\section{Hasil dan Pembahasan}

\subsection{Proyeksi Penumpang dan Barang}

Pendapatan dan biaya operasi KA akan sangat dipengaruhi oleh besaran penumpang dan barang yang diangkut. Proyeksi volume penumpang dan barang tahun 2020 didasari oleh proyeksi yang disusun oleh DJKA (lihat Gambar 3), serta asumsi-asumsi perhitungan sebagaimana disajikan Tabel 1.

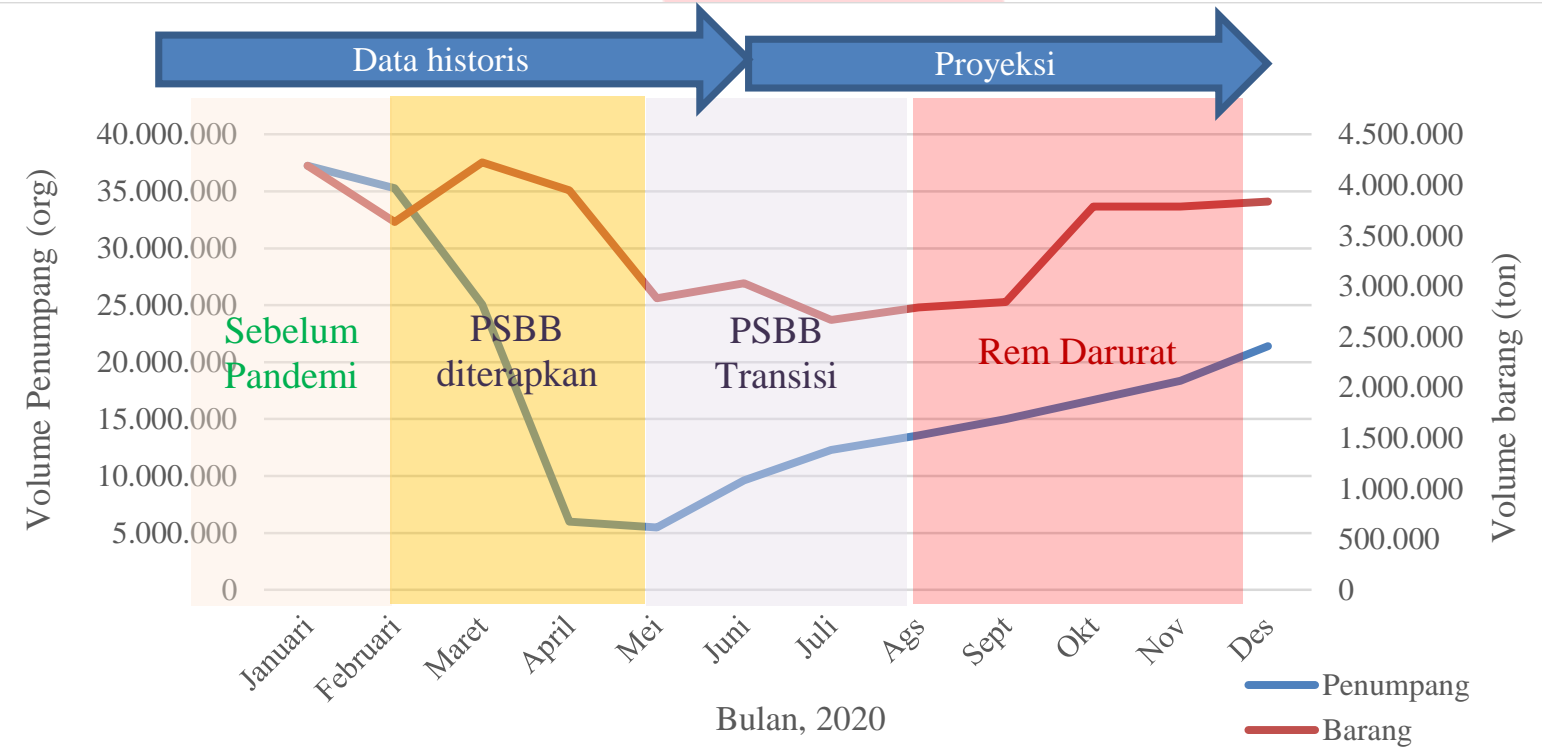

Sumber: Direktorat Jenderal Perekeretaapian, 2020

Gambar 3. Data Historis dan Proyeksi Volume Penumpang dan Barang tahun 2020

Hasil proyeksi volume penumpang tahun 2020 dibandingkan 2019 disajikan dalam Gambar 4.

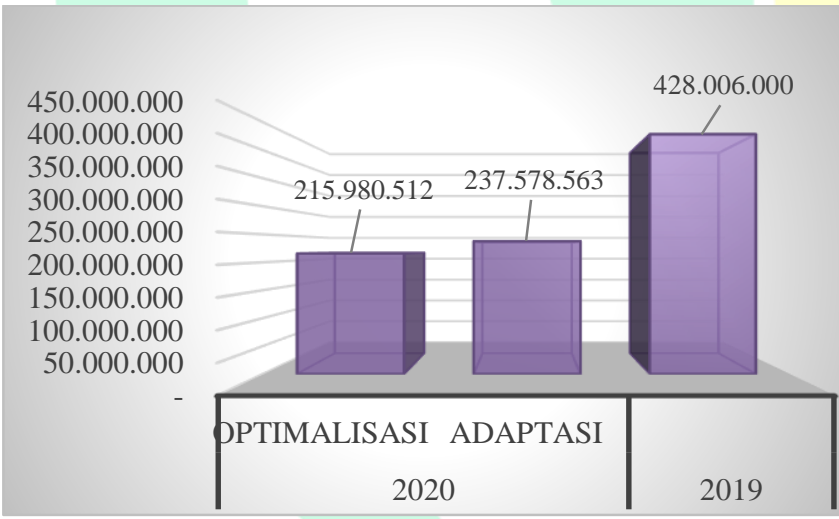

Gambar 4. Proyeksi Jumlah Penumpang 2020

dibandingkan 2019

Gambar tersebut memperlihatkan bahwa proyeksi jumlah penumpang tahun 2020 adalah 215.980.512 penumpang (kebijakan optimasi) dan 237.578.563 penumpang (kebijakan adaptasi). Nilai ini setara dengan 50,5\% dan $55,5 \%$ dibandingkan volume tahun 2019. Jumlah penumpang adaptasi lebih tinggi, karena berdasarkan hasil survei, tingkat penerimaan masyarakat cukup tinggi dalam menerima adaptasi kondisi pandemi.

Proyeksi volume barang disajikan dalam Gambar 5.

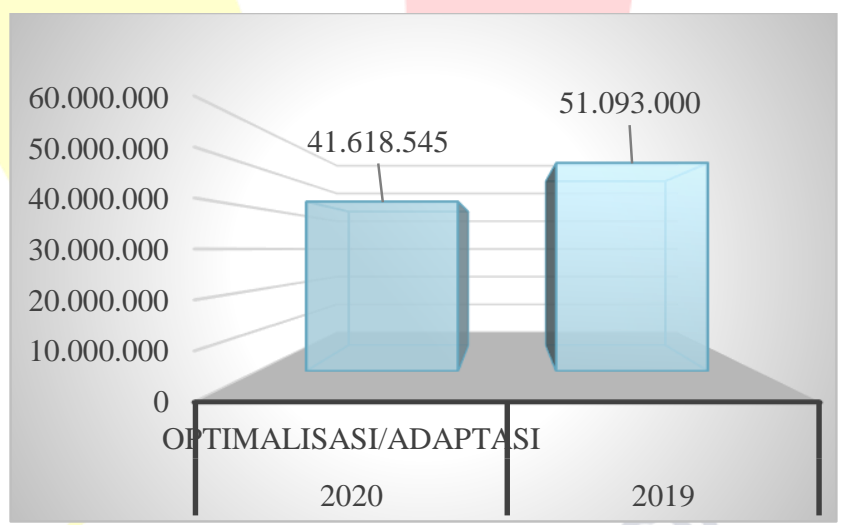

Gambar 5. Proyeksi Volume Barang 2020 dibandingkan 2019

Volume barang baik untuk kebijakan optimasi maupun adaptasi adalah sama, yaitu sebesar 
41.618.545 ton pada tahun 2020, nilai ini setara dengan 81,5\% dibanding volume tahun 2019.

\subsection{Proyeksi Pendapatan}

Profil pendapatan tahun 2019 menunjukkan bahwa angkutan penumpang menyumbang pendapatan terbesar $(42,83 \%)$, diikuti angkutan barang $(30,50 \%)$ dan kompensasi pemerintah $(14,53 \%)$. Sumber pendapatan lain adalah dari non angkutan $(7,97 \%)$ dan pendukung angkutan KA $(4,18 \%)$. Secara lengkap, profil pendapatan angkutan dan usaha lain dari PT. KAI disajikan dalam Tabel 2.

Tabel 2. Profil Pendapatan PT. KAI 2019 (Rp Juta)

\begin{tabular}{|c|c|c|c|c|c|}
\hline \multirow{2}{*}{$\begin{array}{c}\text { Pendapatan Angkutan dan Usaha } \\
\text { Lainnya }\end{array}$} & \multirow{2}{*}{$\begin{array}{c}\text { Realisasi } \\
2019\end{array}$} & \multirow{2}{*}{$\begin{array}{l}\text { Realisasi } \\
2018\end{array}$} & \multicolumn{2}{|c|}{ Kenaikan/ Penurunan } & \multirow{2}{*}{$\begin{array}{c}\text { Proporsi } \\
\text { pendapatan } 2019 \\
(\%)\end{array}$} \\
\hline & & & Selisih & $\%$ & \\
\hline Angkutan penumpang & 9.644 .404 & 8.324 .541 & 1.319 .863 & 15,86 & 42,83 \\
\hline Angkutan barang & 6.868 .634 & 6.317 .462 & 551.172 & 8,72 & 30,50 \\
\hline Pendukung angkutan KA & 940.498 & 823.500 & 116.998 & 14,21 & 4,18 \\
\hline Non angkutan & 1.793 .728 & 1.096 .177 & 697.551 & 63,63 & 7,97 \\
\hline Kompensasi pemerintah & 3.271 .013 & 3.391 .844 & -120.831 & $-3,56$ & 14,53 \\
\hline Jumlah & 22.518 .277 & 19.953 .524 & 2.564 .753 & 12,85 & 100,00 \\
\hline
\end{tabular}

Sumber: Annual Report PT. KAI 2019 (diolah)

Proyeksi pendapatan PT. KAI dengan mempertimbangkan volume penumpang dan barang untuk kebijakan optimasi dan adaptasi disajikan dalam Tabel 3.

Tabel 3. Proyeksi Pendapatan - Kebijakan Optimasi Operasi (Rp M)

\begin{tabular}{|c|c|c|c|c|c|c|c|c|}
\hline \multirow[t]{2}{*}{ No. } & \multirow[t]{2}{*}{ Jenis Pendapatan } & \multicolumn{7}{|c|}{ Tahun } \\
\hline & & $2020 *$ & 2019 & 2018 & 2017 & 2016 & 2015 & 2014 \\
\hline 1 & $\begin{array}{l}\text { Pendapatan Angkutan dan Usaha } \\
\text { Lainnya }\end{array}$ & 11.082 & 17.454 & 15.466 & 13.292 & 10.771 & 10.104 & 8.776 \\
\hline A. & Angkutan Penumpang & 4.867 & 9.644 & 8.325 & 7.050 & 5.675 & 5.344 & 4.577 \\
\hline B. & Angkutan Barang & 5.595 & 6.869 & 6.317 & 5.618 & 4.573 & 4.359 & 4.110 \\
\hline C. & Pendukung Angkutan KA & 620 & 940 & 824 & 624 & 523 & 401 & 89 \\
\hline 2 & Pendapatan Non-Angkutan & 3.684 & 5.065 & 4.488 & 4.647 & 3.693 & 3.835 & 1.702 \\
\hline A. & Pendapatan Aset dan Pihak Ketiga & 1.183 & 1.794 & 1.096 & 1.253 & 807 & 1.002 & 613 \\
\hline B. & Kompensasi Pemerintah & 2.501 & 3.271 & 3.392 & 3.394 & 2.885 & 2.832 & 1.089 \\
\hline & TOTAL PENDAPATAN & 14.766 & 22.518 & 19.954 & 17.939 & 14.463 & 13.939 & 10.478 \\
\hline
\end{tabular}

Sumber: Laporan Keuangan Konsolidasi PT KAI (Persero) Tahun 2014 - 2019 (diolah), hasil perhitungan, 2020

Hasil perhitungan menunjukkan bahwa total pendapatan kebijakan optimasi operasi adalah sebesar $65,57 \%$ dari pendapatan tahun 2019 . Dalam proyeksi pendapatan ini sudah dimasukkan penurunan volume penumpang dan barang, serta asumsi-asumsi penyesuaian insentif pemerintah melalui penerimaan PSO dan IMO. Penerimaan PSO disesuaikan dengan jumlah penumpang yang diangkut, bukan berdasar kontrak awal. Sementara IMO dibayarkan penuh sebagaimana tahun sebelumnya.

Proyeksi pendapatan kebijakan adaptasi pandemi disajikan pada Tabel 4. 
Tabel 4. Proyeksi Pendapatan - Kebijakan Adaptasi Pandemi (Rp M)

\begin{tabular}{|c|c|c|c|c|c|c|c|c|}
\hline \multirow[t]{2}{*}{ No. } & \multirow[t]{2}{*}{ Jenis Pendapatan } & \multicolumn{7}{|c|}{ Tahun } \\
\hline & & $2020 *$ & 2019 & 2018 & 2017 & 2016 & 2015 & 2014 \\
\hline 1 & $\begin{array}{l}\text { Pendapatan Angkutan dan Usaha } \\
\text { Lainnya }\end{array}$ & 11.592 & 17.454 & 15.466 & 13.292 & 10.771 & 10.104 & 8.776 \\
\hline A. & Angkutan Penumpang & 5.353 & 9.644 & 8.325 & 7.050 & 5.675 & 5.344 & 4.577 \\
\hline B. & Angkutan Barang & 5.595 & 6.869 & 6.317 & 5.618 & 4.573 & 4.359 & 4.110 \\
\hline C. & Pendukung Angkutan KA & 644 & 940 & 824 & 624 & 523 & 401 & 89 \\
\hline 2 & Pendapatan Non-Angkutan & 3.468 & 5.065 & 4.488 & 4.647 & 3.693 & 3.835 & 1.702 \\
\hline A. & Pendapatan Aset dan Pihak Ketiga & 1.228 & 1.794 & 1.096 & 1.253 & 807 & 1.002 & 613 \\
\hline B. & Kompensasi Pemerintah & 2.240 & 3.271 & 3.392 & 3.394 & 2.885 & 2.832 & 1.089 \\
\hline & TOTAL PENDAPATAN & 15.061 & 22.518 & 19.954 & 17.939 & 14.463 & 13.939 & 10.478 \\
\hline \multicolumn{9}{|c|}{ * hasil perhitungan } \\
\hline & Proporsi pendapatan $2020 / 2019=$ & $38 \%$ & & & & & & \\
\hline
\end{tabular}

Hasil perhitungan menunjukkan bahwa proyeksi pendapatan kebijakan adaptasi pandemi adalah sebesar $66,88 \%$ dibandingkan tahun 2019. Dalam perhitungan sudah dimasukkan asumsi kenaikan penumpang sebesar $10 \%$ (sebagai akibat tingginya kesiapan pengguna terhadap penerapan protokol COVID - 19) dan penyesuaian PSO, namun tidak memasukkan penyesuaian IMO, sehingga IMO dibayarkan sesuai dengan proporsi jumlah penumpang pada tahun 2020 .

\subsection{Perhitungan Biaya}

Dalam perhitungan biaya, besaran variable cost adalah linier dengan besaran penumpang dan barang, sehingga penurunan penumpang akan berimplikasi pada penurunan biaya. Adapun besaran fixed cost adalah tetap sebagaimana tahun sebelumnya. Berdasarkan identifikasi struktur biaya yang dimiliki oleh PT. KAI, maka item fixed cost dan variable cost pada operasionalisasi KA disajikan dalam Tabel 5.

Tabel 5. Komponen Fixed dan Variable Cost pada Operasionalisasi KA

\begin{tabular}{llll}
\hline \multicolumn{1}{c}{ Fixed Cost } & \multicolumn{1}{c}{ Variable Cost } \\
\hline 1) & Pegawai awak & 1) & Perawatan Sarana \\
\hline 2) & Penyusutan Sarana & 2) & BBM dan Listrik Aliran Atas \\
\hline 3) & Sewa Sarana dan Fasilitas & 3) & Pendukung Operasional dan Angkutan \\
\hline 4) & Asuransi & 4) & Bongkar Muat \\
\hline 5) & Pegawai non-awak & 5) & Terminal Peti Kemas \\
\hline 6) & Perawatan dan Operasi Prasarana & 6) & Beban Keamanan dan Kebersihan \\
\hline 7) & Beban Optimalisasi Aset & 7) & Sewa Prasarana KA (TAC) \\
\hline 8) & Penyusutan Prasarana dan Amortisasi & \multicolumn{2}{l}{} \\
\hline 9) & Beban Stasiun & \\
\hline 10) Perawatan Prasarana Pendukung Angkutan KA &
\end{tabular}

Berdasarkan data dan informasi tersebut, dilakukan perhitungan biaya operasi pada pandemi, sebagaimana disajikan dalam Tabel 6 kebijakan optimasi operasi maupun adaptasi dan 7.

Tabel 6. Proyeksi Biaya - Kebijakan Optimasi Operasi (Rp M)

\begin{tabular}{ccrrrrrrr}
\hline \multirow{2}{*}{ No. $\quad$ Jenis Beban Pokok (Biaya) } & \multicolumn{7}{c}{ Tahun } \\
\cline { 3 - 8 } & & $\mathbf{2 0 2 0} *$ & $\mathbf{2 0 1 9}$ & $\mathbf{2 0 1 8}$ & $\mathbf{2 0 1 7}$ & $\mathbf{2 0 1 6}$ & $\mathbf{2 0 1 5}$ & $\mathbf{2 0 1 4}$ \\
\hline A. $\quad$ Fixed Cost (Rp M) & 9.015 & 9.015 & 7.996 & 7.673 & 5.626 & 5.155 & 4.346 \\
\hline B. Variable Cost (Rp M) & 4.622 & 6.943 & 6.198 & 5.647 & 4.990 & 4.877 & 3.159 \\
\hline FIXED COST (Rp M) & 9.015 & 9.015 & 7.996 & 7.673 & 5.626 & 5.155 & 4.346 \\
\hline VARIABLE COST (Rp M) & 4.622 & 6.943 & 6.198 & 5.647 & 4.990 & 4.877 & 3.159 \\
\hline TOTAL BEBAN POKOK (BIAYA) & 13.637 & 15.958 & 14.194 & 13.320 & 10.617 & 10.032 & 7.505 \\
\hline * hasil perhitungan \\
\hline Perbandingan biaya 2020 terhadap 2019 = 85,5\% \\
\hline Sumber: Laporan Keuangan Konsolidasi PT KAI (Persero) Tahun 2014 - 2019 (diolah), hasil perhitungan, 2020 \\
\hline
\end{tabular}

Hasil perhitungan menunjukkan bahwa biaya operasi kebijakan optimasi tahun 2020 adalah sebesar 85,5\% dibanding tahun 2019. Hasil perhitungan tersebut sudah memasukkan 
perubahan jumlah penumpang dan barang, serta asumsi biaya perawatan dan operasi prasarana yang tetap sebagaimana disampaikan oleh PT. KAI. Selain itu, dimasukkan tambahan biaya pendukung operasional angkutan untuk menjalankan protokol COVID - 19 sebesar 5\%.

Biaya operasi kebijakan adaptasi pandemi disajikan dalam tabel berikut:

Tabel 7. Proyeksi Biaya - Kebijakan Adaptasi Pandemi (Rp M)

\begin{tabular}{|c|c|c|c|c|c|c|c|}
\hline \multirow[t]{2}{*}{ Jenis Beban Pokok (Biaya) } & \multicolumn{7}{|c|}{ Tahun } \\
\hline & $2020 *$ & 2019 & 2018 & 2017 & 2016 & 2015 & 2014 \\
\hline A. Fixed Cost (Rp M) & 9.015 & 9.015 & 7.996 & 7.673 & 5.626 & 5.155 & 4.346 \\
\hline B. Variable Cost (Rp M) & 4.835 & 6.943 & 6.198 & 5.647 & 4.990 & 4.877 & 3.159 \\
\hline FIXED COST $(\operatorname{Rp} M)$ & 9.015 & 9.015 & 7.996 & 7.673 & 5.626 & 5.155 & 4.346 \\
\hline VARIABLE COST $(\operatorname{Rp} M)$ & 4.835 & 6.943 & 6.198 & 5.647 & 4.990 & 4.877 & 3.159 \\
\hline TOTAL BEBAN POKOK (BIAYA) & 13.849 & 15.958 & 14.194 & 13.320 & 10.617 & 10.032 & 7.505 \\
\hline \multicolumn{8}{|l|}{$*$ hasil perhitungan } \\
\hline Perbandingan biaya 2020 terha & $2019=\varepsilon$ & & & & & & \\
\hline
\end{tabular}

Hasil perhitungan menunjukkan bahwa biaya operasi kebijakan adaptasi tahun 2020 adalah sebesar 86,8\% dibanding tahun 2019. Hasil perhitungan tersebut sudah memasukkan perubahan jumlah penumpang dan barang, serta asumsi biaya perawatan dan operasi prasarana yang tetap sebagaimana disampaikan oleh PT. KAI. Selain itu, dimasukkan tambahan biaya pendukung operasional angkutan untuk menjalankan protokol COVID 19 sebesar 5\% serta biaya pencegahan kondisi $3 \mathrm{C}$ termasuk redesain sarana prasarana sebesar 5\%.

\subsection{Perhitungan POBO}

Berdasarkan hasil perhitungan, dapat dilihat perbandingan pendapatan dan biaya sebagaimana disajikan dalam Gambar 6.

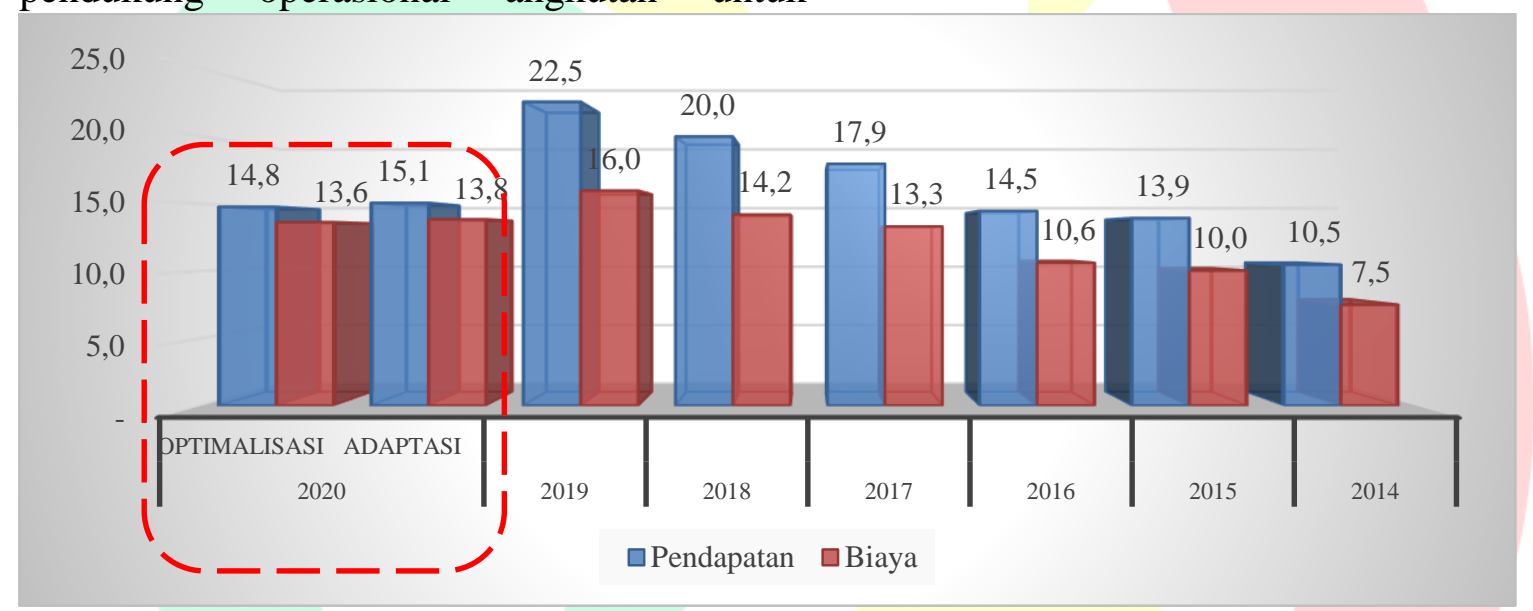

Gambar 6. Perbandingan Pendapatan dan Biaya PT. KAI (Rp T)

Hasil perhitungan memperlihatkan bahwa meskipun turun sangat signifikan dibandingkan tahun sebelumnya, namun jumlah pendapatan operasi masih lebih tinggi dibandingkan biaya pada tahun 2020. Profil ini serupa untuk kebijakan optimasi operasi maupun adaptasi pandemi.

Dalam bentuk rasio, perbandingan Pendapatan dan Biaya Operasi (POBO) disajikan dalam Gambar 7. 


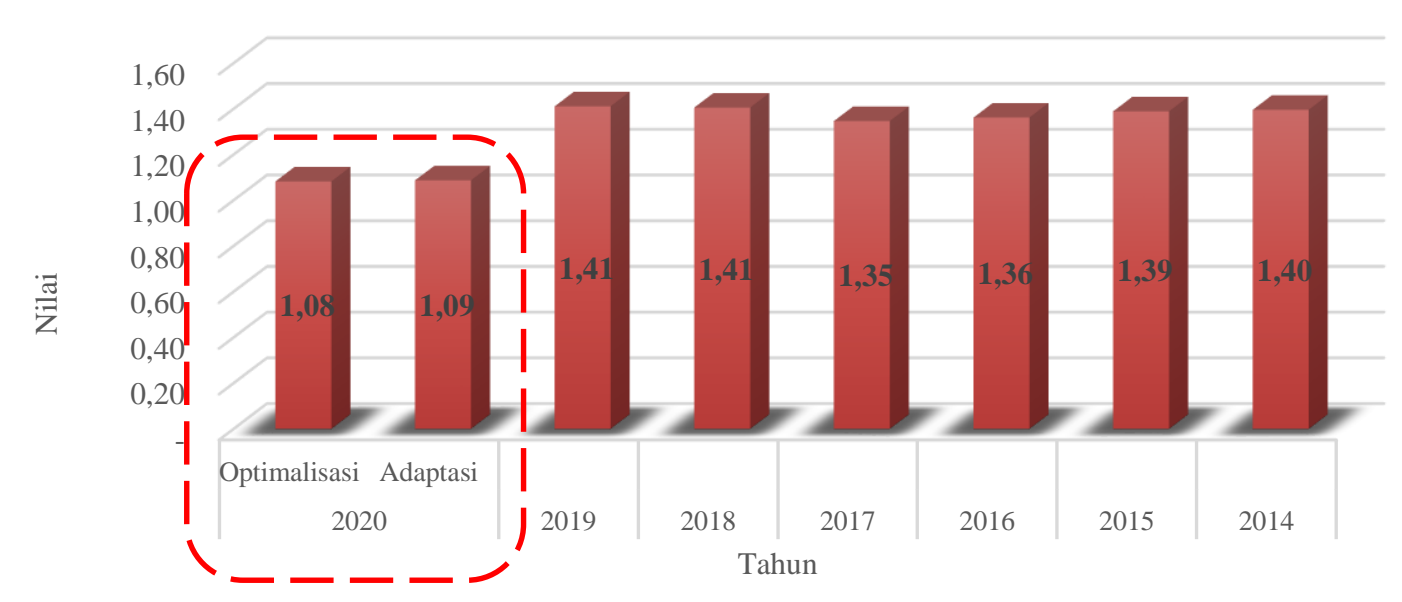

Gambar 7. Perhitungan Nilai POBO

Hasil perhitungan menunjukkan bahwa nilai POBO kedua kebijakan adalah sedikit di atas nilai 1, yaitu 1,08 pada kebijakan optimasi dan 1,09 pada kebijakan adaptasi. Profil ini menunjukkan bahwa ketahanan bisnis perkeretaapian berada pada ambang batas nilai Break Event Point (BEP), jauh di bawah nilai POBO pada tahun-tahun sebelumnya. Hal ini menunjukkan bahwa dampak pandemi adalah sangat signifikan terhadap cash flow perusahaan.
Titik kritis yang mampu ditoleransi oleh bisnis perkeretaapian adalah titik shutdown point, yang menunjukkan kemampuan operator KA untuk membayar fixed cost. Apabila dilakukan simulasi, hasil perhitungan menunjukkan bahwa variasi kondisi kritis dapat terjadi pada beberapa kombinasi, sebagaimana disajikan dalam Tabel 8.

Tabel 8. Variasi Titik Kritis Shutdown Point

\begin{tabular}{l|rr}
\multicolumn{1}{c|}{ Kombinasi } & $\begin{array}{c}\text { \% volume } \\
\text { penumpang 2020 } \\
\text { terhadap volume 2019 }\end{array}$ & $\begin{array}{c}\text { \% volume barang } \\
\text { 2020 terhadap } \\
\text { volume 2019 }\end{array}$ \\
\hline Penumpang tidak parah, barang parah & $52 \%$ & $25 \%$ \\
\hline Penumpang parah, barang tidak parah & $25 \%$ & $59 \%$ \\
\hline Penumpang dan barang sama-sama mengalami penurunan & $40 \%$ & $40 \%$ \\
\hline
\end{tabular}

Hasil perhitungan menunjukkan bahwa secara bersama-sama, shutdown point terjadi pada volume barang dan penumpang sebesar $40 \%$ dibandingkan volume tahun 2019. Apabila dibandingkan dengan volume eksisting sebesar $50,5 \%$ - 55,5\% (volume penumpang), serta $81,5 \%$ (volume barang), maka bisnis perkeretaapian masih memiliki daya tahan sebelum mengalami titik kritis shutdown point.

\section{KESIMPULAN}

Titik kritis shut down point terjadi pada volume penumpang dan barang sebesar $40 \%$ dibandingkan volume tahun 2019. Kondisi saat ini menunjukkan volume penumpang sebesar $50,5 \%-55,5 \%$ dan volume barang sebesar $81,5 \%$ dibandingkan volume tahun 2019, atau lebih tinggi dibandingkan titik kritis. Hal ini menunjukkan bahwa operator masih memiliki daya tahan untuk menjalankan bisnis perkeretaapian. Ketahanan bisnis didukung oleh adanya demand angkutan barang yang masih cukup tinggi. Hal ini wajar, karena kebutuhan konsumen di masa pandemi relatif tetap terhadap barang-barang konsumsi.

\section{Ucapan Terima Kasih}

Terima kasih disampaikan kepada Badan Penelitian dan Pengembangan, Kementerian Perhubungan yang telah memfasilitasi pelaksanaan kajian. Terima kasih juga 
disampaikan kepada PT. Kereta Api Indonesia dan Direktorat Jenderal Perkeretaapian atas data yang dapat diakses secara bebas.

\section{Referensi}

Aloi, Alfredo; Borja Alonso, Juan Benavente, Rubén Cordera, Felipe González, Raquel Lezama-Romanelli, Álvaro López-Parra, Vittorio Mazzei, Lucía Perrucci, Darío Prieto-Quintana, Andrés Rodríguez, Roberto Sañudo. (2020) 'Effects of the COVID-19 lockdown on urban mobility: Empirical evidence from the city of Santander (Spain)', Sustainability (Switzerland). MDPI AG, 12(9). doi: 10.3390/su12093870.

Chen, Yizhe; Yichun Wang, Hui Wang, Zhili Hu, Lin Hua. (2020) 'Controlling Urban Traffic-One of the Useful Methods to Ensure Safety in Wuhan Based on COVID-19 Outbreak', Safety Science. Elsevier, 131(July), p. $104938 . \quad$ doi: https://doi.org/10.1016/j.ssci.2020.104938.

DJKA, K. (2020) 'Dampak pandemi COVID-19 terhadap perkeretaapian'.

Falchetta, G. and Noussan, M. (2020) The Impact of COVID-19 on Transport Demand, Modal Choices, and Sectoral Energy Consumption in Europe Special Issue 'Open Data and Models for Energy and Environment' at Energies-MDPI View project PhD Journey at Politecnico di Torino-Energy Department View. Available at: https://www.researchgate.net/publication/341312437.

KAI (2020) Strategi Pemulihan Bisnis Angkutan Perkeretaapian Pasca Pandemi COVID-19 Pembatasan Sosial Mendorong Penurunan Jumlah Penumpang.

Preston, J. and Bickel, C. (2020) 'And the beat goes on The continued trials and tribulations of passenger rail franchising in Great Britain', Research in Transportation Economics. Elsevier Ltd, (October 2019), p. 100846. doi: 10.1016/j.retrec.2020.100846.

Satya-Lekh P. and Virendra P. (2014). The cost benefit analysis of providing resilience. 4th International Conference on Building Resilience, Building Resilience 2014, 8-10 September. 2014, Salford Quays, United Kingdom

The International Union of Railways. (2020). Management of COVID-19, First estimation of the global economic impact of COVID-19 on Rail Transport.
World Bank (2017) 'Railway Reform: Toolkit for Improving Rail Sector Performance', (June, 2017), pp. $1-428$.

Zhang, J. and Hayashi, Y. (no date) Impacts of COVID-19 on the transport sector and measures as well as recommendations of policies and future research: Analyses based on a world-wide expert survey. 